\title{
Exílios episcopais, identidades exílicas e redes sociais
}

\author{
Episcopal exiles, exile identities and social networks
}

HILLNER, J.; ULRICH J.; ENGBERG, L. (Ed.). Clerical exile in Late

Antiquity. Frankfurt am Main: Peter Lang Edition, 2016. 283 p.

\section{Melissa Moreira Melo Vieira*}

Recebido em: 15/04/2018 Aprovado em: 18/05/2018

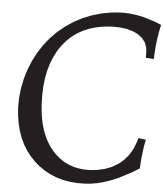

lerical exile in Late Antiquity é a reunião dos resultados do projeto The migration of faith, resultado de uma colaboração entre o Departamento de História da Universidade de Sheffield e o Departamento de Cultura e Sociedade da Universidade de Aarhus. Esse projeto constitui-se em uma pesquisa interdisciplinar internacional que investiga como os exílios de centenas de clérigos de regiões ao redor do Mediterrâneo durante as controvérsias religiosas da Antiguidade Tardia moldaram a instituição da Igreja e a própria relação desta com o poder imperial. Aplicando análises quantitativas e qualitativas a uma ampla gama de fontes - com um foco mais específico em trocas de cartas -, o projeto tem compilado as informações em uma base de dados prosopográficos com clérigos exilados e suas redes socioespaciais. Dez capítulos deste volume são versões revisadas das conferências apresentadas no XVII International Conference on Patristic Studies, realizado entre os dias 10 e 14 de agosto de 2016, na Oxford University.

A obra é dividida em uma introdução e três partes. Em sua introdução, há uma contribuição da organizadora dos trabalhos, Julia Hillner, que aborda as possibilidades de análise dos exílios episcopais a partir do instrumental teórico-metodológico das redes sociais como malhas de poder. Além disso, a autora afirma a necessidade de analisar como outros indivíduos poderiam influenciar em situações de exílio de determinados bispos, como juízes, mensageiros, correspondentes, visitantes, familiares, membros de

\footnotetext{
* Mestre em História pelo Programa de Pós-Graduação em História da Universidade Federal do Espírito Santo sob orientação da Profa. Dra. Érica Cristhyane Morais da Silva, com bolsa da Capes.
} 
congregações e opositores teológicos. Tais influenciadores, que geralmente não são objeto de interesse nas análises de epístolas, são pontos importantes para a reconstrução de uma narrativa exílica, visto que as relações sociais entre bispos exilados e suas redes sociais - que não eram compostas apenas de bispos - possibilitam a reafirmação dos cargos episcopais como essencialmente políticos e que, mesmo em exílio, tais bispos precisavam ter suas autoridades preservadas. Para tanto, utilizavam as cartas como forma de comunicação com suas sés e as comunidades de clérigos partidários a deles.

Na primeira parte, intitulada "Clerical exile and social control", são apresentados artigos de Éric Fournier sobre continuidades e mudanças nos banimentos episcopais durante disputas cristãs. Por meio da análise dos exílios episcopais a partir de Constantino, Éric Fournier argumenta que, com a aproximação entre o poder político e as esferas religiosas, o exílio tornou-se uma ferramenta política de coerção direcionada a bispos que, de uma forma ou outra, representavam uma ameaça ao poder imperial. Sendo assim, ao gradativamente assumir que o exílio de bispos era uma questão de jurisdição imperial, Constantino elaborou uma política de deslocamento que priorizava a ordem nas comunidades cristãs, de modo que, caso algum clérigo representasse uma ameaça à unidade da Igreja, este seria julgado por um concílio e, consequentemente, deslocado para uma região escolhida pelo imperador.

A primeira parte traz também a contribuição de Dirk Rohmann e Harry Mawdsley, que abordam as ordenações clericais e as mudanças de carreiras após o exílio e o mapeamento dos banimentos durante o reino dos Vândalos (435-484). Ambos os autores argumentam que o exílio poderia representar um turning-point na carreira de um bispo, visto que o deslocamento para regiões que possuíam correntes teológicas poderia ser usado por tais clérigos como uma forma de estes afirmarem sua autoridade no que dizia respeito às discussões doutrinárias vigentes. Além disso, Dirk Rohmann, em "Enforced career changes, clerical ordination and exile in Late Antiquity", argumenta que o retorno de bispos às suas sés após o exílio poderia ser extremamente positivo, como foi o caso de Libério de Roma, aclamado pelas comunidades como um mártir, e Hilário, que se tornou uma figura de maior proeminência nas Gálias após o seu retorno à sé de Poitiers.

Na segunda parte, "Clerics in exile", a obra foca em situações particulares de exílio a partir de cartas de bispos como Dionísio de Alexandria, Cipriano de Cartago, Hipólito e Fulgêncio. A atenção dada aos discursos de exílio de Cipriano e Dionísio, pelos historiadores David M. Reis e Jörg Ulrich, respectivamente, demonstra que os exílios eram também situações empregadas pelos clérigos para construírem suas identidades.

Dessa forma, o exílio episcopal era uma das premissas para a construção de identidades martíricas, nas quais alguns bispos, condenados pelo envolvimento em 
conflitos teológicos, utilizavam a situação de isolamento para afirmarem suas posições de autoridade dentro de discussões eclesiásticas, visto que o contato com novas correntes teológicas durante o banimento possibilitava a expansão de redes sociais e, portanto, o diálogo entre clérigos que defendiam credos diversos. Ainda na segunda parte da obra, Jakob Engberg analisa a disseminação das congregações donatistas como consequência dos exílios episcopais.

Na terceira e última parte da obra, "Discourses, legacies and memories of clerical exile", Jennifer Barry, David Reis, Éric Fournier e David Natal apresentam reflexões sobre as retóricas de exílio e como estas foram decisivas para que determinados bispos, como Atanásio de Alexandria e Ambrósio de Milão fossem representados como indivíduos que defenderam uma suposta ortodoxia durante períodos controversos, como o banimento, e, portanto, criaram uma retórica específica que heroicizava suas próprias realizações e resistências.

Jennifer Barry, que contribuiu para a composição do capítulo, tem suas pesquisas atuais direcionadas à discussão das identidades exílicas e como estas possibilitavam a ascensão de grupos teológicos a partir da heroicização de trajetórias individuais. Dentre inúmeros casos, Barry (2016) analisa o exílio de Hilário de Poitiers, no artigo intitulado "Heroic bishops: Hilary of Poitiers's exilic discourse", no qual argumenta que tal bispo, exilado em 356 pelo concílio de Béziers, utilizou seu exílio para construir a sua identidade como um mártir que, por meio de suas ações heroicas, colaborou com a expansão do nicenismo no episcopado oriental.

Apesar das particularidades dos casos estudados em cada capítulo, toda a obra é permeada pela compreensão dos exílios episcopais como um dos principais fenômenos da Antiguidade Tardia, tendo o exílio redimensionado a relação entre episcopado e poder imperial a partir das obras produzidas no exílio. Sendo assim, os autores afastamse de uma interpretação essencialmente religiosa das controvérsias ocorridas entre os séculos IV e VII, visto que o próprio papel de bispos como Ambrósio de Milão e Atanásio de Alexandria deve ser analisado sob uma perspectiva política dentro do processo de institucionalização e burocratização da Igreja. Dentro dessa perspectiva, os exílios eram produtos de uma política de deslocamento direcionada a personagens políticos que, por motivos específicos, representavam uma ameaça a uma pretensa unidade almejada pelo poder imperial.

A obra, além disso, é permeada por uma interpretação dos exílios episcopais como um fenômeno que, além de abranger as esferas jurídicas, políticas e sociais do Império, possibilitava um intercâmbio cultural entre os episcopados ocidental e oriental no que concernia às distintas interpretações doutrinárias que estes possuíam e às características 
disciplinares de tais regiões. Tal interpretação demonstra um esforço em renovar as perspectivas historiográficas acerca das narrativas de bispos que, durante séculos, foram interpretadas somente a partir de um ponto de vista teológico.

$\mathrm{O}$ projeto The migration of faith mapeou, pelo recorte temporal de $325 \mathrm{e}$ 600 , as relações entre bispos exilados, bem como suas respectivas trocas de cartas, rivalidades e favores. A partir disso, a obra revela-se inovadora por tratar o exílio como um potencializador de redes sociais, em detrimento da antiga noção generalizada do exílio episcopal como um banimento violento, isolador e que necessariamente destituía os bispos de suas sés. Desse modo, Clerical exile in Late Antiquity segue os mesmos caminhos de autores como Adam Schor (2011), em Theodoret's people: social networks and religious conflict in Late Roman Syria, e Elizabeth Clark (1992), em The origenist controversy. the cultural construction of an Early Christian debate, ao analisarem as controvérsias religiosas e os consequentes banimentos de bispos como pontos focais para o estabelecimento de redes de apoio.

\section{Referências}

BARRY, J. Heroic bishops: Hilary of Poitiers's exilic discourse. Vigiliae Christianae, v. 70, p. 1-20, 2016.

CLARK, E. The Origenist controversy: the cultural construction of an Early Christian debate. Princeton: Princeton University Press, 1992.

HILLNER, J.; ULRICH J.; ENGBERG, L. (Ed.). Clerical exile in Late Antiquity. Frankfurt: Peter Lang Edition, 2016.

SCHOR, A. M. Theodoret's people: social networks and religious conflict in Late Roman Syria. Berkeley: University of California Press, 2011. 